\title{
Indonesia's Transformation to Gross Split Contract: an Evaluation of Energy Worker Regulation
}

\author{
Ranitya Ganindha \\ Faculty of Law \\ Brawijaya University \\ Malang, Indonesia \\ r.ganindha@at.ub.ac.id
}

\author{
Setiawan Wicaksono \\ Faculty of Law \\ Brawijaya University \\ Malang, Indonesia \\ setiawanwicaksono@ub.ac.id
}

\author{
A.A.A. Nanda Saraswati \\ Faculty of Law \\ Brawijaya University \\ Malang, Indonesia \\ anandasaraswati@ub.ac.id
}

\begin{abstract}
This paper aims to analyze the evaluation of the energy worker regulation that has been transformed to gross split contract. As the Government of Indonesia changed the PSC scheme with cost recovery to the scheme of gross split revenue contract through the Regulation of Minister of Energy and Mineral Resources No. 52 Year 2017 on Amendment to Regulation of the Minister of Energy and Mineral Resources No. 8 Year 2017 on the Gross Split Revenue Contract, the production sharing is set for the base split, which can then be adjusted to the revenue-generating components. This is unlike the conventional profit-sharing contracts, where the share of production between the Government and contractor is fixed. While the new system is expected to reduce the replacement cost incurred by the government when using the PSC scheme, it arises several issues. The oil and gas operator is given freedom to operate without government interference. When the oil and gas work contract expired, one of the things that comes to mind is whether the old worker will be re-employed by a new operator or not. With article 33 of the 1945 Constitution of the Republic of Indonesia as the basis for implementation in the economic sector, including oil and gas, we can see the contradiction between cost efficiency and social protection for all citizens. The results show that there are no regulations that specifically regulate the status of oil and gas workers at the time of contract expiration. Therefore, the need for protection is indispensable. Several steps may be taken, including the adoption of provisions in the Transfer of Undertakings (Protection of Employment) Regulations Year 2006 into the law of labor-related legislation in Indonesia as well as by streamlining the Regulation of Minister of Energy and Mineral Resources No. 15 Year 2015 on Management of Oil and Gas Working Areas Whose Contract of Cooperation is Expired.
\end{abstract}

Keywords - gross split, workers, oil and gas

\section{INTRODUCTION}

The investment sector of oil and gas industry has a long history for Indonesia. Biological resources with geodetic diversity and geological basins offer abundant natural potential. The oil and gas sector is still attracting investors. However, in recent decades this sector has declined as a result of the natural aging of the oil field, the rate of renewed reserves and the lack of exploration and investment activities. In addition, one reas on of the decrease of investments in Indonesia is the legal uncertainty and disharmony of rules related to mining law.

The oil and gas industry, particularly those in the upstream sector, is an important sector for domestic economic conditions. In addition to increase energy needs, upstream oil and gas business activities play a role as Indonesia's foreign exchange contributors, help provide raw materials for other business activities, and help open jobs.[1] Until now, there are about 86 regions with oil and gas reserves,[1] which recorded being undertaken by a number of upstream oil and gas companies that are bound to Cooperation Contracts (CC) with the government.[2]

One of the steps taken by the government to maintain investment in oil and natural gas management sector is to create a package of policies that bring equity and benefits to all parties, as well as friendly investment. Currently, all activities within the scope of oil and gas are regulated under Law No.22 Year 2001 on Oil and Natural Gas. Furthermore, matters concerning Upstream Oil and Gas Business Activities are regulated in Government Regulation No.35 Year 2004 concerning Upstream Oil and Gas Business Activities.

The scheme of cooperation contracts used by the government from 1965 to 2017 is Production Sharing Contract (PSC) with cost recovery. In this scheme, there are returns on operating costs by the government that have been is sued by the contractor during the conduct of exploration and exploitation activities. That is, in this scheme, the government will indirectly share the cost risks with the contractors. All costs in the early stages until the exploration is borne by the government. This is why even though Indonesia's oil and gas PSC is said to be one of the heaviest fiscal regimes in the world, upstream oil and gas investors are still interested in becoming contractors of oil and gas cooperation contracts in Indonesia.

\section{DISCUSSION}

Despite expectation to bring justice for both parties, contract scheme with cost recovery often leads to disputes, such as the contractor inefficiency in operating costs. Reimbursement of the costs of losses to investors as compensation in oil and gas activities is often disputed at the time of the audit by the State Audit Board because it is considered detrimental to the State's finances. The determination of cost recovery also often causes a problem between the contractor and the government represented by the Special Unit for Upstream Oil and Gas Operations (SKK Migas) on who is authorized to determine the amount of replacement. In addition, the cost recovery scheme is 
considered inconsistent with Article 6 paragraph (2) letter c of Law No.22 Year 2001 on Oil and Gas.

Therefore, the Government of Indonesia changed the PSC scheme with Cost recovery to the scheme of contract for the gross split share through the Regulation of the Minister of Energy and Mineral Resources No.8 Year 2017 which not long after was changed into the Regulation of the Minister of Energy and Mineral Resources No.52 Year 2017 on the Amendment to Regulation of the Minister of Energy and Mineral Resources No.8 Year 2017 on Gross Split Revenue Contract.[3] In the regulation, the government made a new breakthrough by replacing the previous PSC Cost Recovery scheme with PSC Gross Split. In this scheme, the government will no longer pay attention to the return of production cost, so the profit sharing will be done directly at the gross stage. ${ }^{1}$ Nevertheless, the government will still take a share of the results which split amount ${ }^{2}$ has been set at the beginning of the contract. ${ }^{3}$

Unlike conventional profit-sharing contracts, where the share of production between the Government and the Contractor is fixed, the production sharing in the Gross Split profit sharing contract system is set for the base split, which can then be adjusted to the variable split and progressive split revenue-sharing, in accordance with the status and stages of production of the work area, the natural conditions of the field, the price of petroleum, and the amount of production.[4]

The calculation of gross split will vary to each work area. A definite calculation is found in the percentage of Split Base. For the oil split base, $57 \%$ is set to become part of the State and $43 \%$ becomes part of the Contractor. While for natural gas, the State's share is 52\% and the Contractor's share is $48 \%$. In addition to the percentage of base split, both the State and the Contractor may obtain a larger share by adding calculations from 10 variable components and 2 other progressive components. This makes the Gross Split scheme attractive to investors to manage oil and gas work areas, including non-conventional working areas that have greater challenges.[5]

The amount of reimbursement that must be issued by the government has experienced an increasing trend every year. Cost recovery in 2010 was approximately US \$ 11.7 billion and increased to US \$ 16.2 billion in 2014. Although based on data of 2015 and 2016 (unaudited), the amount of cost recovery decreased to US \$ 13.7 billion and US \$ 11.5 billion due to low world oil prices. In 2016, the Government's oil and gas revenue was only US \$ 9.9 billion or lower than the cost recovery which is about US $\$ 11.4$ billion. The condition where the cost recovery is greater compared to the State's share of revenue has occurred since 2015. Therefore, with the gross split scheme, operating costs are fully the responsibility of the Contractors. Unlike contracts for cost recovery schemes, the operating costs are ultimately the responsibility of the Government. Contractors will be encouraged to be more efficient as the operating costs

\footnotetext{
${ }^{1}$ What is referred as 'gross' phase is the division of gross shares, not the nett shares after reduced by cost production.

${ }^{2}$ The referred Split is the amount of percentage from the division of oil and gas production result.

${ }^{3}$ What is referred as "settled in the beginning" is that the amount of split has been fixed in the Regulation of the Minister on Gross Split, which is different from the previous scheme.
}

are the responsibility of the Contractors. The more efficient are the Contractors, the better the profits will be.[6]

The change of scheme is also expected to bring about a change in the contractor's mindset. From the mindset that has been "relaxed", since all the incurred costs until the exploration phase will be replaced by the government, it becomes a cost conception or efficient in every action because the cost incurred by the contractor will not be replaced by the government. Therefore, the implementing operator must be able to reduce costs as efficient as possible so that production costs are getting smaller and will give more profit. Such efficiency can be done in various sectors such as vendor selection, use of technology, use of labor, and so forth.

Although it appears to be answering the problems contained in the Cost Recovery scheme, however, when further examined, the Gross Split scheme is actually causing much debate. As mentioned before, that in the activities of upstream oil and gas business of Indonesia uses Cooperation Contract system which is civil. Oil and Gas Production Sharing Contracts also have contract termination periods as well as other contracts. On the date specified in the contract, then the contract will expire. The end of the contract then becomes a legal event, because it brings legal consequences and moves the rule of law to work.

These legal consequences affect the Cooperation Contract Contractor (CCC) as the operator responsible for restoring the location which will be abandoned or for ensuring the site is safe and free from dispute if it is to be handed over to other operators. The CCC shall settle all obligations to any third party, either the sub-contractor working on it or any other third party related to the operation of its operations. Another important consequence of the law is that the CCC must terminate the employment relationship with its workers and provide compensation for layoffs that have been arranged or mutually agreed upon.[6]

The selling price of world oil which also experienced a decline of up to USD 50 per barrel makes oil and gas operators have difficulties. The efficiency of production costs including the threat of Termination of Employment for employees becomes a new problem. CCC basically has regulated the layoffs is sue that resulted from the end of the production sharing contract and its compensation in the joint work agreement of the Compensation in the form of the provision of benefits managed by the Pension Fund Program of Financial Institutions. When the layoffs occur after the contract expires, the CCC no longer has the obligation to work with its workers.

When oil and gas cooperation contracts end, one of the things that workers think about is whether the new management operator will re-employ the workers of the old operator. When the cooperation contract between the government and investors is still using the old scheme of production sharing contract cost recovery, the government still plays a considerable role in the determination of labor, as well as the use of technology to be applied. However, through the implementation of the new Profit Sharing scheme with Gross Split Mechanism, CCC has the flexibility to carry out its operational activities including the use of technology and the management of its personnel.

It has the meaning that the government no longer intervenes in oil and gas business activities conducted by 
CCC including in the matter of employment. Thus, there is no guarantee that new CCC operators will re-hire workers from previous operators. Guarantee of continuity of work is a matter of principle as it concerns the fate of the workers.[6]

Article 33 of the 1945 Constitution of the Republic of Indonesia becomes the basis for implementation in the economic sector, including oil and gas. Cost efficiency and social protection for all citizens has always been a contradiction.[7] Quoting Eli Rusliana's opinion, Article 33 of the 1945 Constitution, paragraphs (1), (2) and (3) have not changed as the text in the original text. While regarding the content of Article 33 of the 1945 Constitution, paragraph (4) and (5) are the result of Amendment IV in 2002. The existence of the word "fair efficiency" has changed the whole veiled intention to incorporate the views of economic neoliberalis $\mathrm{m}$, which paved the way for new capitalis $\mathrm{m}$ and imperialism, in Article 33 of the 1945 Constitution. Why so is because the word "efficiency" in the economy is oriented towards maximum gain (for business entities) and maximum satisfaction (for individuals). The notion is a manifestation of economic liberalis $m$ through the free market. The free market has paved the way for the good of the market to evict the good fortune of the people. Free markets will displace the poor instead of displacing poverty. With the word "fair efficiency", the interests of the persons they represent are transformed into the public interest (individual preferences are changed into social preferences).[7] The conflict between economic benefits of efficiency and social protection in the 1945 Constitution can also occur in the scheme of gross split contracts.

Gross Split sharing scheme is efficient. Imposing all costs to operators without subsidy from the government encourages contractors to cut production costs. Non-valueadded items will be removed. Intangible issues such as environment and labor is sues may become a sidelined right. [8]

The case illustration below illustrates the efficiency in labor management. An oil and gas operator requiring 100 workers to perform well drilling work using the technology agreed upon in the PSC Cost Recovery contract. However, when using the Gross Split scheme, the contractor chooses a technology that makes the use of labor become less. Such circumstances will make otherworkers lose their jobs.

According to the Conference of the National Workers Union, there are several matters related to the imposition of Gross Split which could harm workers' rights, including:

1. No State control over the amount of use of Foreign Workers in CCC

2. The State can no longer interfere with the CCC's policy regarding the status of the workers

3. Workers do not get protection from the State which has been done by SKK Migas

4. There is no supervision and control over minimum welfare standards to be met by investors

5. The process of reducing workers, such as Termination of Employment, is done legally without any other considerations such as national interest

6. It is difficult to unite the voice in the national tripartite process related to the enforcement of labor regulations due to the characteristics of the enforcement of labor regulations regarding the characteristics of oil and gas sector which is different from other sectors.[8]

CCC in conducting its business activities certainly cannot run its own operational activities. There are many partners who support business activities. The efficiency performed by operators due to the gross split scheme is not impossible to reduce the link in the operation. Workers who depend on their fate to the employ ment partners may also be affected by the layoffs arising from the efficiency being made. In the year 2018, there are eight oil and gas operators whose contract will expire. The Government through SKK Migas has made an appeal to new operators to keep employing old workers to avoid social unrest. However, through a gross split mechanism the full authority is in the hands of the contractor.

The problem of labor shifting is not only happening in Indonesia, AEC has even issued special rules related to the transfer of employees in Transfer of Undertakings (Protection of Employment) Regulations 2006. The rapid economic growth makes merger, consolidation, and acquisition become common practice. That is, the transition process from the old owner to the new owner does not cause layoffs. The implementation of Gross Split's contract in Indonesia requires the government's role as a counterweight. Exploration of oil and gas sector should not only aim at efficiency and profit, but also pay attention to social we lfare. Oil and gas operators will indeed perform various efficiencies to obtain optimal results. However, the government must act as a counterweight so that the social protection aspect is not abandoned.

The provisions in Transfer of Undertakings (Protection of Emp loyment) Regulations 2006 are then popularly known as TUPE Principle, which is then widely adopted by other countries, one of which is Indonesia. The Constitutional Court in its Decision Number 27 / PUU-IX / 2011 dated January 17, 2012 adopted the TUPE principle in the context of outsourcing in examining the material review case of Act No. 13 Year 2003 on Labor. 4

Implementation of the TUPE principle in outsourcing according to the Constitutional Court is in the event of a shift in the implementation of outsourced work. The existing working relationship between the worker and the old outsourcing company must be forwarded by the new outs ourcing company. The terms of employment should not be reduced except with the consent of the workers. This TUPE principle applies as long as the work still exists and the status of the employment agreement is a Specific Time Working Agreement (PKWT). [9]

Following up on the Decision of the Constitutional Court, the government through the Ministry of Labor and Transmigration then is sued the Regulation of the Minister of Labor and Transmigration No.19 Year 2010 on Terms of Submission of Some Implementation of Work to Other Companies. Until now, there is no legislation that specifically regulates the protection of the status of oil and gas workers at the time of contract expiration.

Originally the applicant in the case requested that the Constitutional Court declare the provisions on out sourcing is declared contrary to the Constitution. Upon the request of the Court, then decided that the provisions on oursourcing are contradict ory to the Constitution unless the TUPE principle is exercised. 
In addition, the step that can be taken is by streamlining the Regulation of the Minister of Energy and Mineral Resources No. 15 Year 2015 on the management of the Working Area of Oil and Gas where the contract has ended. Through this Ministerial Regulation, the Government has requested that oil and gas operators applying for the management of the Oil and Gas Working Area to submit a management transfer plan whose contents indicate that it will employ existing workers. The Regulation of the Minister of Labor and Transmigration No. 19 Year 2012 which regulates the outsourced workforce stipulates that oil and gas operators must still employ the already hired workers as long as the work is available and qualifies. The applicable terms of employment remain the same unless amended by mutual agreement. In the event that there are workers who cannot be accommodated, the CCC must be able to prove that the works for the concerned no longer exist, or the relevant ones do not qualify because there are physical limitations.

The regulation concerning the transition process of the management of oil and gas working area, especially related to labor, has not been regulated separately in a legislative regulation, so that the Government can take progressive step by making a rule that accommodate workers' rights.

\section{REFERENCES}

[1] S. H.S, Hukum Pertambangan di Indonesia. Jakarta: Rajawali Pers, 2008.

[2] "List of CCC," SKK Migas. [Online]. Available: http://skkmigas.go.id/daftar-kkks. [Accessed: 14-Dec-2017].

[3] "Scheme of Oil and Gas Gross Split Contract, Reduction on the Weaknesses of Cost Recovery Scheme," Ministry of Energy and Mineral Resources of the Recpublic of Indonesia. [Online]. Available: $\quad$ https://www.esdm.go.id/id/media-center/arsipberita/skema-kont rak-migas-gross-split-reduksikelemahan-skemacost-recovery . [Accessed: 28-Dec-2017].

[4] "Hukum Online." [Online]. Available: http://www.hukumonline.com/. [Accessed: 01-May-2018].

[5] " Gross Split Lebih Baik untuk Mewujudkan Energi Berkeadilan di Indonesia" [Online]. Available: https://kominfo.go.id/index.php/content/det ai//9109/gross-splitlebih-baik-untuk-mewujudkan-energi-berkeadilan-diindonesia/0/artikel_gpr.

[6] "Gross Split Lebih Baik Untuk Mewujudkan Energi Berkeadilan Untuk Indonesia." [Online]. Available: https:/kominfo.go.id. [Accessed: 01-May-2018].

[7] E. Ruslina, Dasar Perekonomian Indonesia dalam Penyimpangan Mandat Konstitusi UUD Negara tahun 1945. Jakarta: P3IH FH UMJ, 2013

[8] Papers from Department of Law, Directorate General of Oil and Gas which is presented in the Forum of Law on Oil and Gas 2017, Jogjakarta.

[9] Decision of the Constitutional Court Number 27/PUU-IX/2011 dated 17 January 2012 Pg. 45 